Psychology of Language and Communication 2018, Vol. 22, No. 1

\title{
Sciendo
}

DOI: $10.2478 /$ plc-2018-0024

\author{
HANNA JAKUBOWICZ BATORÉO \\ Universidade Aberta, Lisboa, Portugal
}

\section{METAPHORICAL COMPETENCE IN MULTILINGUAL CONTEXT OF LANGUAGE ACQUISITION AND LEARNING}

\begin{abstract}
It has been defended since Gibbs (1994) that in proper contexts people mostly use the metaphorical asset of a message rather than its literal meaning, which means that we tend to express ourselves metaphorically and that conceptual metaphors and metonymies are features of communicative interaction. In the present paper we discuss the notion of metaphorical competence (Aleshtar \& Dowlatabadi, 2014: 1895) in the process of language acquisition and learning of a (multilingual) speaker in a multilingual context. Based on previous studies by Sinha and Jansen (2004), Kövecses (2005), Palmer \& Sharifian (2007), Gibbs \& Colston (2012) and Sharifian (2015), among others, we postulate that research in the area should be centred not exclusively on Language but on interaction in a triangle Cognition - Language - Culture, We defend the way one conceptualises the world is based on bodily experience, and is mediated by culture (cf. Yu, 2003, 2009; Batoréo, 2017a). In this study we present research from different language backgrounds both occidental (European Portuguese, English and Polish) and oriental ones (Mandarin Chinese). It focuses on conceptualization of emotions (e.g., emotional expression of feeling hungry) and moral values (e.g. courage). The analysis shows that it implies culture anchorage and/or physiological and cultural embodiment. We defend that conceptual appropriateness and metaphor awareness play a fundamental role in the acquisition of figurative language (cf. Doiz \& Elizari, 2013), which is at least partially motivated, and thus can be object of insightful learning (cf. Boers et al., 2004).

Key words: metaphorical competence, language acquisition and learning, cognitive linguistics, cultural linguistics, (physiological and cultural) embodiment, figurative language, conceptual appropriateness, metaphor awareness, Chinese, English, Polish, Portuguese.
\end{abstract}

Address for correspondence: Hanna Jakubowicz Batoréo, Palácio Ceia, R. Escola Politécnica 141-147, 1269-001 Lisboa, Portugal. E-mail: hannabatoreo@hotmail.com 


\section{Introduction}

The starting point of our study is to answer the question: why is it important for a multilingual speaker to be conceptually appropriate while expressing emotions and values in the different languages that (s)he acquires and learns?

Speaking of appropriateness in the process of language acquisition and learning has been traditionally language structure oriented, whereas the context of figurative language has been understood as arbitrary in nature and thus requiring mostly blind memorization. Nevertheless, research developed over the last thirty years in the field of Cognitive Linguistics shows that the scope of the background should not be merely linguistic, but should rather focus on Language, Cognition and Culture interactions. Based on studies by Sinha and Jansen (2004), Kövecses (2005), and Sharifian (2015), among others, we defend that interaction of Cognition - Language - Culture is centred on the importance of the body and embodiment in conceptualization, and is mediated by culture, emphasizing the role of body and everyday experience in shaping the mind and creating specific conceptualisations.

Studies of figurative language in the field (e.g., Gibbs, 1994; Kövecses, 1990 and 2005; Lakoff, 1987) have shown that figurative idioms are believed to be (at least partially) motivated. It is defended that although idiomatic meaning is not fully predictable, its derivation from a literal sense can be explained by means of cognitive mechanisms - such as conceptual metaphors and metonymies (cf. Batoréo, 2017a) - responsible for specific motivation in the process of learning. Boers (2001), Boers et al. (2004) and Boers et al. (2007) defend that associating an idiom with its etymology enhances retention, as the etymological information is likely to call up a mental image of a concrete scene that can then be stored in memory alongside the verbal form (Boers et al., 2007: 43). According to Dual Coding Theory (Clark \& Paivio, 1991), this mental image can subsequently provide an extra conceptual pathway for recalling.

Research $^{1}$ dedicated to figurative language in Cognitive Linguistics (e.g., Gibbs 1994) postulate that in proper communicative contexts people mostly use the metaphorical asset of a message rather than its literal meaning. It means that in everyday common contexts we express ourselves metaphorically, making metaphors features of communicative interaction. At the same time, L2 studies (Danesi, 1992, 1993, 1995; Doiz \& Elizari, 2013) postulate that in order to make metaphors work we need to develop a special

\footnotetext{
1 "Cognitive linguistics was at the time of its inception all about conceptual metaphors, and also about metonymies, image schemas and blending. As a result of the rapid development and diversification of cognitive linguistics, new topics and methodologies emerged, gradually pushing conceptual metaphors and metonymies out of the centre stage. However, vigorous research into how conceptual metaphors and metonymies interact and motivate grammatical structures, discourse types and communication processes that we have recently witnessed justifies its coming back into the limelight.” In: http://braga.ucp.pt/ftt4/call_for_papers/ (Accessed on April 19, 2018).
} 
sort of competence - metaphorical competence - which requires becoming conceptually fluent and conceptually appropriate in a given language. If we function in a multilingual context, speaking various languages that represent different cultural backgrounds, it may result in a demanding and complex task of cognitive, linguistic and cultural character.

Taking into consideration the research referenced above, in the present paper we defend that:

(i) appropriateness in language is to be taken not only in its linguistic dimension but also in the conceptual and cultural, in a Language Cognition - Culture triangle, creating a complex multidisciplinary background for language acquisition and learning;

(ii) figurative language is cognitively grounded and is not completely arbitrary but at least partially motivated by its original usage; it can be the object of insightful learning of its etymology and cultural grounding in idioms and/or (semi-)fixed linguistic expressions with a figurative basis;

(iii) conceptual appropriateness in metaphorical competence and metaphor awareness play a fundamental role in the acquisition of figurative language, which serves as a window to access diversity and specificity of conceptualisations in different languages;

(iv) interaction in a Cognition - Language - Culture triangle is centred on the importance of the body and everyday bodily experience and activities: embodied conceptualizations mediated by culture give origin to physiological and/or cultural embodiment.

In the present paper the issue of multilingual context is analysed in a restricted sense of multilingual learning context, focusing on conceptualisation patterns grounded in cognitive mechanisms such as conceptual metaphor and metonymy, which a (multilingual) speaker acquires (naturally) and/or learns (formally) in a new language context ${ }^{2}$. In this process, (s)he is faced with different conceptualisation patterns in different languages that require not only linguistic fluency but also cognitive effort and cultural anchoring in order to be mastered. This is how metaphorical competence grounds our capacity to understand and produce metaphorical language in natural discourse. We centre our research on discussing figurative language, and especially fixed and idiomatic expressions in a chosen set of languages (English, European Portuguese, Polish and Chinese). Thus, we postulate that studying figurative language is: (i) a privileged window to study this capacity, (ii) the best way to approach and understand the conceptualisation patterns in focus, (iii) as well

2 This is the reason why we refer jointly to the "acquisition and learning" process. We do not address here other related issues such as multilingual communication or learning more than one language, since our study is focused on metaphorical competence. 
as the best way to understand the role that metaphorical competence plays in language acquisition and learning.

Research in Cognitive Linguistics centred on interaction in the Cognition - Language - Culture triangle defends conceptualisation of experience in image schemas (i.e., schematic versions of images). This means that images are representations of specific embodied experiences (Croft \& Cruse, 2004: 44) and suggests that many concepts (such as those of emotion, for instance) are embodied with a basis in bodily experience because "[t]he kind of body we have and how it functions influence and shape what and how we mean (...)" (Yu, 2009: 178). It is also defended that physiological embodiment is rooted and anchored in culture (Sinha \& Jansen, 2004; Palmer \& Sharifian, 2007), whereas embodied theories of cognition in Cognitive Sciences postulate that our minds are embodied and shape the way we think and speak:

One of the most salient events in cognitive science in recent years is the rise of work on embodied cognition and language (Bergen, 2005; Gibbs, 2006a). Embodied theories of cognition emphasize the degree to which minds are embodied and how they are distributed across brains, bodies, and the world. Most of the empirical work on embodied thought and language has focused on the way bodies and ongoing bodily activity shape people's thinking and speaking about concrete objects and events." (Gibbs and Colston, 2012: 114).

The present study is divided in four sections: (1) Introduction; (2) Metaphorical competence in language acquisition and learning; (3) Examples of embodiment and cultural grounding; and (4) Discussion and final remarks. In order to illustrate the phenomena referred to in the introductory section, we first explain what we mean by metaphorical competence in language acquisition and learning, and then we present three groups of examples with different types of conceptualisation originated by cultural grounding and embodiment (both physiological and cultural) observed in different languages and cultures. The exemplification comes from three languages embedded in the so called occidental culture of Latin origin (English, European Portuguese and Polish) and one oriental language and culture (Mandarin Chinese). In example 1, we focus on the emotional aspects of speaking about hunger; in example 2, we present the emotional aspects of referring to a small time distance, and, in example 3, we discuss how courage can be embodied in different cultures and languages. Then, we discuss how metaphorical competence is built up in the context of different languages and cultures in language acquisition and learning. 


\section{Metaphorical competence in language acquisition and learning}

In the field of Language, Acquisition and Learning, there are various types of competences that a speaker of a language - a native or a non-native tongue - has to master. If, traditionally, linguistic competence was understood as the system of linguistic knowledge of native speakers of a given language, nowadays after decades of theoretical discussion, it is defended that a competent speaker of a language has to master not only different sorts of linguistic competence - as, for example phonological, syntactical, semantical, lexical, discursive and/or narrative - but (s)he has to be competent communicatively, which means (s)he is expected to show good communicative competence, in order not only to know the language but also to be able to use it in a correct and accurate way in a given context.

Nevertheless, if - as defended by Gibbs (1994) - we communicate using metaphorical rather than literate language, having good linguistic and communicative competence may not be enough for a speaker to be an accurate and competent user of a language. In this context metaphorical competence is required, going beyond other competences that a speaker has to master when (s)he wants to speak a given language. Metaphorical competence is understood here as "the ability to comprehend and use metaphors in a given language as used in natural discourse" (Aleshtar \& Dowlatabadi, 2014: 1895). It implies that speakers should not only be linguistically and communicatively appropriate but also conceptually appropriate, learning how to express themselves in the target language, and using figurative speech that is congruent with the culture. As stressed in last years' literature in Second Language Acquisition (cf. Shirasi \& Talebinezhad 2013; Aleshtar \& Dowlatabadi, 2014), this has been one of more prominent subject matters in the field, after having been called "a neglected dimension in the L2 Learning" by Danesi (1992) twenty years before (cf. Shirasi \& Talebinezhad, 2013: 136). According to Danesi (1992, 1993 and 1995), metaphorical competence requires conceptual fluency to describe "the ability of speakers to tap effectively into the cultural and linguistic reservoir of verbal images" (Shirasi \& Talebinezhad, 2013: 136). Thus, being conceptually fluent in a language means "to know how that language contemplates or illustrates its concepts based on the metaphorical metaphors structuring" (Shirasi \& Talebinezhad, 2013: 136). Following these definitions, metaphorical competence is a sort of umbrella term to refer to an individual's ability to comprehend and produce metaphorical language in natural discourse by means of different cognitive mechanisms, such as conceptual metaphors and metonymies. As metaphors and metonymies have entailments that organize our experience and create necessary realities, and require either projecting or mapping one domain of human experience into another (metaphors), or mapping within the same domain (metonymies), this competence focuses on the ability to detect the similarity between disparate 
domains, to use one domain to talk about another, as well as to entail different aspects of the same domain. Metaphorical competence requires metaphor awareness and strategies for comprehending and creating new domains in order to express new experiences. In a multilingual context, both conceptual appropriateness in metaphorical competence and metaphor awareness play a fundamental role in the process of figurative language acquisition (cf. Doiz \& Elizari, 2013).

\section{Examples of embodiment and cultural grounding}

If we recognize that in everyday life it is "metaphors we live by" (following the title of the fundamental book in the area of Cognitive Linguistics, by Lakoff and Johnson), then it is important to understand how these metaphors are created, for instance in the process of conceptualisation of emotions (such as sadness or joy) and values (such as sense of loyalty or courage). This process requires conceptual metaphorisation originating in cultural grounding and/or physiological and cultural embodiment, and it differs from culture to culture: it is defended (Yu, 2007), for instance, that different cultures map different body organs - such as the heart, gallbladder or liver - into different emotions (cf. Batoréo, 2015, 2017 a, b \& c). This means, for example, that if in English history we have heroic leaders such as Braveheart or Richard the Lionheart, well-known for their courage/ bravery, in English (and in many other occidental languages) it is the heart that is considered the organ responsible for the embodiment of courage, as shown also by the etymology of the word ${ }^{3}$. Nevertheless, there are languages and cultures in which the embodiment of courage is not in the heart but in a different organ (see example 3, in section 3 , below). This means that learning a new language implies understanding how these conceptualisations are constructed in order to make learners become conceptually fluent and able to learn insightfully figurative expressions of a new language.

To illustrate the phenomena defined above, we present three groups of examples with different types of conceptualisation and embodiment (physiological and/or cultural) in different languages and cultures. In example 1 , we focus on the emotional aspects of speaking about hunger; in example 2, we present the emotional aspects of referring to a very small distance, and in example 3 we discuss how courage can be embodied in different cultures and languages.

\footnotetext{
3 The root of the word courage is 'cor', the Latin word for heart. Courage originally meant "to speak one's mind by telling all one's heart." In: https://www.merriam-webster.com/dictionary/courage
} 


\section{Example 1: Emotional expression of hunger in an everyday situation}

In order to understand how metaphorical competence works in particular languages, let's look at an example of emotional expression of hunger in three different languages: English, (European) Portuguese and Polish.

Meaning (in a common, everyday situation): "I am starving and I need to eat as soon as possible".
(1a) English:
I'm so hungry that I could eat an ox
(1b) (European) Portuguese:
(b1) Tenho a barriga a dar horas'/ 'Tenho o estômago a dar horas' (lit.: "I am having my belly telling the time"/ "My belly is striking the hour/ "I have my stomach telling the time").
(b2) Tenho a barriga colada às costas (lit.: "My belly is glued/plastered to my back").
(1c) Polish:
(c1) Kiszki mi marsza graja. (lit. "My bowels/ guts are marching on")
(c2) Zjadłabym konia z kopytami/ Wilka bym zjadla' (lit.: "I'm so hungry that I could eat a horse with its hooves (horseshoes on)/ I could eat a wolf")

In the examples in (1), if we want to say 'I am very hungry' in (European) Portuguese (1b), in everyday discourse we shall probably use a common language specific metaphor and say 'tenho a barriga a dar horas' (lit.: "I am having my belly telling the time", meaning "I am starving and I need to eat as soon as possible." In an analogous situation in English (1a), we would say: 'I' $m$ so hungry that I could eat an ox', whereas in Polish (1c) a common expression will be: 'Zjadtabym konia z kopytami' (lit.: "(I'm so hungry) I could eat a horse with its hooves"4 or 'Wilka bym zjadla' (lit. "I could eat a wolf"). As the examples in (1) show, each of the languages exemplified here uses a different sort of metaphor to express an emotional way of referring to the same concept of hunger, and uses a different sort of conceptualisation of the phenomenon.

Broadly speaking, two types of conceptualisation can be observed in the examples above. The first one is physically embodied, as shown in examples (b1), (b2), and (c1), whereas the second is culturally rooted, as illustrated in (1a) and (1c2). This means that in the case of the expressions analysed in (1), the English example (1a) is culturally grounded, whereas

\footnotetext{
${ }_{4}$ The same expression is reported to be used in Canadian French (cf. https://forum.wordreference. com/threads/im-so-hungry-i-could-eat-a-horse.1027205/
} 
the (European) Portuguese in (1b) has its roots in physiological embodiment in (1b2), and both physiological and cultural embodiment in (1b1). The Polish examples in (1c) show both physical embodiment (1c1) and cultural anchoring (1c2).

In Portuguese (1b), physiological embodiment is observed both in (1b1) and (1b2), but the latter expression is less complex than the former. In (1b2), the hungry stomach is conceptualised as an empty container (with no food in it), which shrinks in a way that it gets plastered to its "host's" back. The metaphor HUNGRY STOMACH IS AN EMPTY CONTAINER is metonymically motivated, since there is a causal relation between the lack of food and the shrinking of the stomach. In (1b1), the embodiment is also physiological, as there is an organ of the human body - the belly - within which digestion is conceptualised. It does not mean that Portuguese bellies have built-in clocks (which might be a possible guess from a non-fluent, unprepared non-native speaker), but that they function according to a meal day schedule where meals are served at fixed hours. If the meal is not served, the belly is empty and makes physiological noise in order to remind its "host" the meal cannot be missed. This physiological embodiment is anchored culturally in a strong meal-oriented day schedule of the Portuguese society, giving origin to cultural embodiment. The conceptual metaphor used in this case may be proposed as HUNGRY STOMACH IS A MEAL TIME STRIKING MECHANISM. It is metonymically and metaphorically motivated, because the physiological noise the intestines make sounds like the pattern of a clock-like mechanism striking hours. The expression is opaque to a non-native speaker, as (s)he is not culturally aware of this cultural schema, which has to be consciously analysed with the explicit conceptual and cultural insight. If we compare the expressions in (1) from a non-native learner point of view, (1a), (1b2) and in (1c) are probably not as opaque as the Portuguese idiomatic expression in (1b1). These constructions are semi-fixed, which probably makes the process of learning easier than in the case of a non-transparent idiomatic expression, as e.g., in (1b1).

In the expressions presented in English (1a) and in Polish (1c2) cultural reference is made to an emblematic figure of a large-sized animal, relevant culturally in each country: an ox in England and a horse or a wolf in Poland. This reference "measures" the hunger somebody is (introspectively) feeling, as its conceptualisation requires the voracious eating of a large-sized animal. In the Polish case (1c2), the reference can be made either to a horse or to a wolf, and the horse is chosen with the reference being made to "its hooves included" in order to upgrade the scale of the experienced emotion. In these cases a pattern of expressing hunger is created by comparing it to the capacity of eating a horse/ a wolf/ an ox (or any other large-sized animal culturally motivated, as illustrated in some other European languages ${ }^{5}$ ). Traditionally, these expressions are analysed as hyperboles, since the expressed feeling is

${ }_{5}$ Cf. https://forum.wordreference.com/threads/im-so-hungry-i-could-eat-a-horse.1027205/ 
highly exaggerated (nobody can really eat an ox or an entire horse in a real life). From the cognitive point of view though, we use a conceptual metaphor of FEELING VERY HUNGRY IS FEELING ABLE TO EAT VORACIOUSLY A BIG-SIZED ANIMAL. This metaphor is metonymically motivated by a set of animals that are culturally relevant in a given cultural area.

In the case of the wolf reference, there is also the expression "a wolf's appetite" (as in Polish, 'wilczy apetyt'), meaning that somebody is extremely hungry. In this case the reference is not made to the human capacity of voraciously eating an animal as large as a wolf, as was shown by the examples discussed above. In this case the reference is made rather to a wolf's capacity to gormandise ${ }^{6}$ : in order to understand how big somebody's appetite is we conceptualise it as a wolf's appetite, creating another conceptual metaphor: FEELING VERY HUNGRY IS HAVING A WOLF'S APPETITE. Both the metaphors discussed here illustrate how we conceptualise our necessity to eat in an emotional way: in the first case we refer to the size of our own appetite, whereas in the second the instantiation of the paradigm is made by a voracious animal known in a given culture ${ }^{7}$.

The three groups of examples in (1) show that each of the referred languages has a single underlying conceptual system that emerges at the idiomatic level in figurative language. One language specific conceptual structure cannot be used in a different language, as shown by the pseudo-English expressions "*I am having my belly telling the time" or "*I'm so hungry that I could eat a horse with its hooves", linguistically built up with English syntax and lexicon but having no relevant meaning, as they illustrate a lack of conceptual fluency and conceptual awareness that is specific to English. If you are a non-native speaker of English and you want to say in an everyday situation that you are starving, you have to restructure conceptually and learn that your reference has to be made - culturally and linguistically - to an ox, in a specific English semi-fixed expression. This means that learning a new tongue involves conceptual restructuring (for instance,

\footnotetext{
6 "A well-fed, healthy adult wolf can go for weeks without eating, and then can make up for it by eating about 18 pounds of food at a time, their diet varied according to available prey" In: http://www. edodaniel.com/show/ sld037.htm

7 In many other European languages - spoken either in Europe or in South America - the same cultural reference takes place (cf. https://forum.wordreference.com/threads/im-so-hungry-i-could-eat-a-horse.1027205/):

1. Usually, reference is made to a horse (Spanish, French, Italian, Russian, Turkish, Romanian), a wolf (German, French, Romanian, Latvian, Turkish, Greek, Slovenian), a cow (Spanish), a bear (German), a donkey (French), a beast (Lithuanian), a lamb (Greek), and an ox (Slovenian). Some languages make reference to more than one animal. Occasionally, the reference can be made to a lion, hardly related to European culture.

2. In Brazilian Portuguese (BP), the reference can be made either to a horse or an ox or even a lion:

(i) 'Tenho (estou com) tanta fome que comeria um cavalo' (lit.: "I am so hungry that I could eat a horse");

(ii) 'Tenho (estou com) tanta fome que comeria um boi com guampa e tudo' (Lit. "I'm so hungry that I could eat an ox with horn and everything");

(iii) 'Estou com uma fome de leão' (Lit.: "I am as hungry as a lion").

(iv) In BP, there is also a specific metaphor metonymically motivated of a human organ shrinking out of hunger: 'Estou com tanta fome que meu intestino grosso está comendo o fino' (Lit.: "I'm so hungry my large intestine is eating the small one").
} 
from an internal belly clock or a horse with its hooves included to a native ox) and implies transforming into a new cultural system:

$[O]$ ne's first language, together with its underlying conceptual structure, is acquired within one's own cultural system, but the learning of a second language involves conceptual restructuring. That is, second language acquisition takes place in the process of transforming into a new cultural system. (Yu, 2007: 78).

\section{Example 2: emotional expression of a small time distance in an everyday situation}

Example (2) illustrates the emotional expression of a very small distance in three different languages: English, (European) Portuguese, and Polish.

Meaning (in a common, everyday situation): "something happened narrowly, barely, as if nearly no time was included".

(2a) English: By the skin of (one's) teeth

(2b) (European) Por um fio or Por um triz

Portuguese: (lit.: "by a thread") (lit.: "by a hair")

(2c) Polish: $\quad O$ wtos

(lit.: "by a hair")

The metaphor used in examples (2) is: BARELY ANY TIME IS HARDLY ANY SPACE understood as an instantiation of a broader metaphor TIME IS SPACE.

The English expression in (2a), 'by the skin of (one's) teeth', is used to refer to a very small time distance in an emotional way, meaning that something happened narrowly or barely, usually indicating a narrow escape from disaster. The expression is of biblical origin ${ }^{8}$ and the image used here is the amount of thickness of the (imaginary) skin of one's teeth: as teeth don't have skin, the allusion is made to the teeth's surface, indicating that there is no thickness - meaning nearly no distance - to be referred to. This expression is often used to allude to something that almost didn't happen (such as, for instance, missing a meeting, missing a plane, passing at school with difficulties, escaping from disaster or accident), as illustrated in in the following expressions $^{9}$ (2a) (i) to (iv):

(2a)

(i) My car wouldn't start this morning. I just made it here by the skin of my teeth!

(ii) I got through calculus class by the skin of my teeth.

\footnotetext{
${ }^{8}$ The phrase first appears in English in the Geneva Bible, 1560, in Job 19:20, which provides a literal translation of the original Hebrew: "I haue escaped with the skinne of my tethe." In: http://www.phrases.org. uk/meanings/83000.html.

${ }^{9}$ All the English usage examples (i) to (iv) are quoted according to: https://idioms.thefreedictionary.com/ by+the+skin+of+teeth
} 
(iii) I got to the airport a few minutes late and missed the plane by the skin of my teeth.

(iv) Lloyd escaped from the burning building by the skin of his teeth.

The embodiment presented here is of cultural origin with its roots in the Bible, but it can be anchored physiologically, indicating the imaginary "skin of our teeth" as the place of no real physical dimension.

On the other hand, the biblical image used in English does not occur in (European) Portuguese (2b) or Polish (2c). Instead, a "hair distance" with something happening (or not) "by a hair distance" 10 is indicated. Portuguese actually uses two parallel constructions with the same meaning: 'por um triz' (lit.; "by a hair distance") and 'por um fio' (lit.: "by a thread distance"), whereas, the corresponding expression in Polish (2c) is 'o włos' (lit.: "by a hair distance") or 'o maty włos' (lit.: "by a small hair distance"). In order to compare the usage of the English expressions (2a) with Portuguese ${ }^{11}(2 b)$ and Polish $^{12}$ (2c) in examples (i) to (iv) below:

(2b)

(i) Foi por um fio/ por um triz que cheguei cá.

(I just made it here by the skin of my teeth!)

(ii) Fiz o seminário por um fiol por um triz.

(I got through this seminar by the skin of my teeth.)

(iii) Por um triz/ por um fio ela perdeu o avião.

(She missed the plane by the skin of her teeth.)

(iv) Por um triz/ por um fio ele escapou do incêndio.

(He escaped from the fire by the skin of his teeth.)

(2c)

(i) O maty wtos, a nie przyjechalabym na czas.

(By the skin of my teeth I will not come on time!)

(ii) O maty włos nie zdalabym egazaminu.

(I almost did not pass my examinations).

(iii) O mały włos uderzyłbym $w$ drzewo, gdy na mój pas wjechat samochód jadacy z naprzeciwka.

(I would almost hit a tree when a car coming in from the opposite

direction came into my lane).

(iv) Wydaje się, że w moim wieku śmierć jest $\underline{o}$ włos.

(It seems in my age life is hanging by a thread).

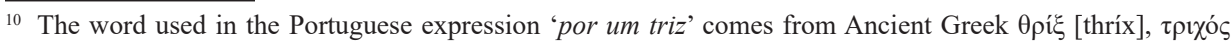
[trikhós] meaning hair, and is not productive in Portuguese any more (Portuguese uses instead 'pelo' ou 'cabelo'). The etymology is proposed by José Pedro Machado, but it is referred to as controversial. In: https:// pt.wiktionary.org/wiki/triz.

${ }_{11}$ Cf. https://www.significados.com.br/por-um-triz/; http://www.dicionarioinformal.com.br/por+um+fio/

12 Cf. http://sjp.pwn.pl/slowniki/o\%20w\%C5\%82os.html; https://sjp.pwn.pl/poradnia/haslo/Smierc-jest-o-wlos; $16627 . h$ tml
} 
Comparing the usage examples of the figurative expressions in the three languages in (2), we can observe some linguistic restrictions in the constructions of syntactic and semantic character that have to be discussed in a separate study ${ }^{13}$.

As for the embodiment observed in the three languages in (2), both Polish (2c) and Portuguese (2b) use a 'hair' as a strategy for measuring a nearly-nonexisting distance. At the same time, both English (2a) and Portuguese (2b) use a 'thread' as the same sort of strategy. It is curious to observe that a hair is the thinnest part of the body imaginable, corresponding to a thread in the bodyexternal world. In the first case, we have a physiological embodiment, centred on a body organ, whereas in the second case we have a cultural embodiment, referring to a traditional everyday human bodily activity, such as weaving and producing textiles.

It is interesting to notice that English also has an analogous expression to those observed in Polish and Portuguese: 'hanging by a thread' ${ }^{14}$, as in: 'his life is hanging by a thread' (Port. 'a vida dele está por um fio', Pol.'jest o wtos od śmierci/jego życie wisi na włosku). All of them are idiomatic or fixed in character and show greater formal semantic and syntactic restrictions than the expressions presented in (2). The image used here and the cultural embodiment are the same in the three analysed languages with their roots in history and culture of Ancient Greece. It is said to derive from a banquet held by King Dionysius for Damocles, a courtier of ancient Syracuse, where Damocles was seated under a sword suspended by a single hair, which symbolized his tenuous position in the court. In this way both the sword and Damocles' life were said to be hanging by a thread: both in a literary and in a figurative meaning.

\section{Example 3: expression of courage in different cultures}

In the subsection of example (3), we are going to focus our study on the expression of courage in different cultures, taking into consideration the differences observed on one hand in the broadly speaking occidental languages of Latin cultural influence and, on the other, in the Chinese culture and language. We use the word courage here in a very broad sense to cover a large spectrum of meanings also represented in English by such words as boldness, bravery or daring. ${ }^{15}$

\footnotetext{
${ }_{13}$ It seems that in the constructions we discuss here speakers of English (in 2a) and of Portuguese (in 2b) prefer to refer to something that was managed to be done, whereas speakers of Polish refer to something that was not managed to be done, using a hypothetical construction to express it. These syntactic and pragmatic restrictions can be observed in discrepancies between Polish original examples and their English equivalents given in brackets in examples (i) and (ii) in (2c). This issue requires a special and more thorough comparison of language usage based on data from linguistic corpora in a separate study.

${ }_{14}$ Cf. https://www.englishexperts.com.br/forum/como-dizer-estar-por-um-fio-em-ingles-t7340.html

${ }^{15} \mathrm{Cf}$. "I am aware that words of this kind could be language-specific and should be used with caution in analyzing one language using a different language (see e.g., Goddard \& Wierzbicka, 1994; Wierzbicka, 1992, 1999)." (Yu, 2003: 15-16).
} 
As referred above in the introduction to the section of examples, English and many other occidental languages with strong Latin cultural roots consider courage to be housed in the heart, the organ responsible for its embodiment. It can be observed in the etymology ${ }^{16}$ of the word 'courage' in English as well as in its counterparts in the Romance languages (as Portuguese 'coragem', for instance) and in many expressions, such as names of brave historical leaders (e.g., Braveheart or Richard the Lionheart). In the occidental culture the heart is not only the place where courage originates, but also where emotions are placed, as observed in the expressions: 'you are breaking my heart', 'sick at heart', 'sing/speak/pour/cry one's heart out', 'heart breaking news', 'heartbroken person', 'from the bottom of my heart', etc. However, emotions like disgust, repulsion or feeling worried are often conceptualised as localised deep inside in our body, as for instance in the liver or intestines. In the latter, the reference is often made either to sexual organs (examples $3 \mathrm{~b}$, bellow) or the intestines referred to as guts or bowels in informal language and slang. For instance, in Polish ${ }^{17}$ we can say (i) 'mieć coś na wątrobie' (lit. "have something on the liver"), meaning excessive worries or (ii) 'Kiszki/flaki się we mnie przewracaja' (lit. "my guts are turning over"), meaning disgust and/or repulsion.

No matter what our cultural origins are, if we learn a new language from a different culture we have to take into consideration that the embodiment observed in it can be totally different from the one we know from our native tongue and are inclined to take for granted. As body organs can be conceptualised in different ways in different languages, the process originates different embodiments and it is important in the process of language learning in order to create conceptual fluency in a new tongue and make the speakers become metaphorically aware and competent.

The examples presented in (3) focus on the emotional expression of courage first in Chinese (3a) and then are illustrated by three languages coming from occidental cultures of Latin origin, analysed in previous examples (3b).

If we are a non-native speaker of Chinese, it is important to understand that Chinese culture is strongly determined by traditional Chinese medicine and philosophy. According to Yu (2007: 70), in Chinese medicine, the internal organs of the human body are divided into two major classes: one called zang (脏), of primary importance and yin in character, and the second one called $f u$ (腑), of secondary importance and yang. The five primary organs zang are liver, heart, spleen, lung, and kidney, and each of them is matched with a secondary organ $f u$ : respectively, gallbladder, small intestine, stomach, large intestine, and bladder. There are also extra $f u$ organs that refer to the three visceral cavities housing the internal organs. Yu stresses (2003: 18) that the heart

\footnotetext{
${ }_{16}$ The root of the word 'courage' is 'cor', the Latin word for heart. See footnote 1, above.

$17 \mathrm{http}: / /$ www.edupedia.pl/words/index/show/475215_slownik_frazeologiczny-miec_cos_na_watrobie. html; http://www.edupedia.pl/words/index/show/476012_slownik_frazeologiczny-przewracaja_sie_ komus_ kiszki_flaki_i_in_pot.html
} 
and the gallbladder hold a special relation between them. Whereas the heart is the organ of the emperor, ruling all psychological and mental activities, it is the gallbladder, considered the emperor's minister, that is the organ of justice which makes judgments and decisions, guided by the heart. As the primary and the secondary organs are closely related, the disease of the gallbladder, for example, will affect the functions of the heart. For instance, if the vital energy qi of gallbladder rises to trouble the heart, the patient will display unusual states of emotion:

If the $q i$ in both the heart and the gallbladder is "weak" or "vacuous" $(x u)$, the patient may feel scared for no or any reason, and be laden with misgivings. If "the emperor (i.e., the heart) and the prime minister (i.e., the gallbladder) help each other, they will together promote vitality and preserve life" (Wang et al., 1997, p. 759). (Yu, 2003: 18).

Given the specific philosophical and medicinal roots of Chinese culture, $\mathrm{Yu}$ (2003:16) postulates the existence of two Chinese metaphors GALLBLADDER IS CONTAINER OF COURAGE and COURAGE IS QI (GASEOUS VITAL ENERGY) IN GALLBLADDER that explain the specificity of Chinese physiological and the cultural embodiment that underlies the figurative language in expression of bravery. $\operatorname{Examples}^{18}$ (3a) (i) to (vii) illustrate both these metaphors:

(3a)

(i)

(ii)

(iii)

\section{Expression of courage in Chinese}

Wu-dan zhi ren shishi nan.

(without-gall MOD people everything difficult)

"everything appears difficult to people without gallbladder."

Meaning: Those who are not brave (i.e., do not have gallbladder) consider everything difficult.

hun-shen shi-dan

(whole-body is-gall)

"be every inch a hero; be the embodiment of value"

Meaning: If you have a gallbladder as big as your body, you are embodiment of courage.

qige-tou bage-dan

(seven-heads eight-galls)

"extremely bold and not afraid of death"

Meaning: If you feel like having eight gallbladders you are extremely brave.

\footnotetext{
18 All the Chinese examples in this section follow Yu (2003: 15). In the gloss line, the gallbladder is referred in its short form 'gall'.
} 
(iv) gu-dan yingxiong

(single-gall hero)

"a lone fighter"

Meaning: Having only one gallbladder makes you a lonely fighter.

(v) qun-wei qun-dan

(crowd-might crowd-gall)

"(display) mass heroism and daring"

Meaning: Mass gallbladders make you powerful and daring.

(vi) Hao da de danzi!

(how big MOD gall)

(lit.: How big your gallbladder is!)"

"what a nerve!

Meaning: The size of your gallbladder guarantees your bravery.

(vii) Ni da-zhe-danzi qu, bu-yao pa.

(you big-PRT-gall go don't-be afraid)

(lit. Go ahead with your gallbladder big)

"go right ahead and don't be afraid."

Meaning: Try to make your gallbladder big (be brave) and don't be afraid.

Examples (3a) (i) to (vii) illustrate the central role that the gallbladder plays in housing courage in Chinese culture. The image created by the embodiment - both physiological and cultural - implies that you can be seen as a brave person only if you are considered to have a gallbladder; the (imaginary) lack of this organ means lack of courage, whereas its (imaginary) size (i.e. being big or not) determines the scale of your bravery. This means that the dimension of the value is determined by the organ itself, its size, as well as the number of gallbladders you can count on: the bigger the imaginary number of organs the higher the effectiveness and visibility of your courage, determining the final result of your brave and daring performance.

The sort of embodiment observed in Chinese culture determines the figurative language used by its speakers. If you are a non-native speaker of Chinese you need to restructure conceptually; in order to refer to the gallbladder native speakers adopt a new conceptualisation, and transit into a new cultural system. Without the insight of how the gallbladder houses courage for a Chinese speaker, it is not possible to express emotions in Chinese, understand or speak the language with competence. For an occidental non-native speaker, the role the gallbladder plays in Chinese imagery may seem strange because in occidental cultures and languages it is not common ${ }^{19}$ to refer the organ in

\footnotetext{
${ }_{19}$ In order to provide some examples, we consulted some sites of figurative expressions referring gallbladder
} in English, Polish and Portuguese, but no figurative expressions were found. 
everyday language or to have it referred to metaphorically, probably due to the taboo restrictions (varying from culture to culture) in referring to some internal human organs.

Taking into consideration some exemplification from occidental languages in (3b), it is interesting to observe what internal organs they conceptualise as housing courage. The examples in (3b) are expressions ${ }^{20}$ illustrating the embodiment of courage (and power) in English, European Portuguese and Polish, and come from very informal speech and/or slang.

\section{(3b) Expression of courage in some occidental languages (examples)}

(i) English

'Have the guts'

e. g. 'Does he have the guts to dive off the highboard?'

'Have the balls'

e. g. 'You don't even have the balls to ask for a girl's number.'

(ii) European Portuguese

'Ter tomates'

(Lit.: "have tomatoes")

e. g. 'É preciso ter tomates para falar com um general desta maneira!'

(Lit. "you need to have the tomatoes to speak to your general in this way".

(iii) Polish

Miec jaja

(Lit.: "have eggs")

e. g. Co to znaczy mieć jaja, czyli rzecz o męskiej odwadze.

(Lit. "What does it mean to have eggs or speaking of male courage")

In (3b), the general informal reference is made either to the internal organs as 'guts', in English, or to testicles in all three of the languages taken into consideration, conceptualised either as balls (in English, and in European Portuguese interjections) or eggs ${ }^{21}$ (in Polish) or even tomatoes (in European Portuguese), as a symbol of (sexual) power. Sometimes the use of 'stomach' is found instead of ' $g u t s$ ', but it is considered obsolete ${ }^{22}$.

${ }_{20}$ The examples follow the sites: for English http://www.dictionary.com/browse/have-the-guts, for Portuguese http://www.urbandictionary.com/define.php?term=have\%20the\%20ball, and for Polish http://www.szkolaojcostwa.pl/artykuly/meska-odwaga/

${ }^{21}$ It is interesting that in Polish having eggs refers both to males and females, whereas in other languages in which the same expression occurs it can have gender restrictions. Spanish, for instance, uses the same reference in the expression 'tener huevos', but it can be used in reference to males only, whereas in the case of females the expression 'tener ovários' ("have ovaries") is used in this sense (personal communication).

${ }^{22} \mathrm{http} / /$ www.dictionary.com/browse/have-the-guts The same restricted usage is found in Portuguese for 'ter estômago' ("have a stomach") in the sense of to be daring, to be able to stand up for something: http://www. dicionarioinformal.com.br/ter\%20est $\% \mathrm{C} 3 \% \mathrm{~B} 4 \mathrm{mago} /$ 
The insightful analysis we presented here of how courage is conceptualised in different languages coming from different cultures and how different embodiments are built up in each one gives important clues from the area of Language Acquisition and Learning. If, on the one hand, you come from the Chinese Culture and you want to speak an occidental language, or, on the other hand, if you are an occidental non-native speaker of Chinese, you have to understand that knowing the everyday usage of a new language implies knowing the type of embodiment it uses to refer to courage (or any other value) and learning it in language-in-usage using figurative expressions. This cultural switch may imply crossing barriers of taboos such as referring to some body organs that we are not used to referring to in our native language, but that makes part of the cultural imagery of metaphorical competence of a new tongue we are learning.

\section{Discussion and final remarks}

In the present paper we defend that the process of language acquisition and learning is not only about linguistic appropriateness, as the research in the area has defended for decades. We understand that in order to use a (new) language it is not enough to be linguistically and communicatively competent in order to construct syntactically and semantically correct discourse in communicatively appropriate situations. Taking into consideration all the research developed in the area of Cognitive Linguistics in the last decades, and especially Gibbs' (1994) postulate that in everyday speech we use figurative language that is metaphorically grounded, we defend that the speaker of a (new) language must be competent not only linguistically and communicatively but also conceptually and culturally. This perspective switches the focus of the research in the area from the Language itself to the Language - Cognition - Culture triangle, creating a complex multidisciplinary background to the respective research. It also focuses on metaphorical competence, as one of the basic competences to be developed in the process of language acquisition and learning.

In the research presented here the issue of multilingual context was analysed in a restricted sense of multilingual learning context, focusing on conceptualisation patterns that a multilingual speaker has to acquire and learn in a new (multilingual) language context. In this process different conceptualisation patterns are mastered, which requires specific cognitive effort and/or cultural anchoring, and gives origin to metaphorical competence, i.e. our capacity to understand and produce figurative language in natural discourse.

We centred our research on discussing figurative language, and especially fixed and idiomatic expressions in a given set of languages. With this strategy we defend that studying figurative language is: (i) a privileged window to 
study metaphorical competence, (ii) the best way to approach and understand the conceptualisation patterns in focus, and (iii) understand what metaphorical competence is required for in the process of language acquisition and learning.

In order to illustrate the phenomena introduced and defined in the first part of the study, we presented three groups of examples with different types of conceptualisation originating from cultural grounding and embodiment observed in different languages and cultures. Broadly speaking, the exemplification came from two different cultures - the occidental, of Latin origin, and the oriental anchored in Chinese culture - and tongues, such as English, European Portuguese, Polish and Mandarin Chinese. First, we focused on the emotional aspects of speaking about hunger and on the emotional aspects of referring to a small time distance in the case of the above mentioned three European languages. Then, we illustrated the embodiment of courage first in Chinese, showing how it was rooted in Chinese philosophy and medicine, and then comparing it to different types of embodiment observed in the occidental cultures we focused upon.

In the exemplification of cultures and languages we provided, we intended to show how important it is to be metaphorically competent in order to build up conceptual metaphors and metonymies and use metaphoric conceptualisations that a given language requires for rooting its figurative language, given that different languages map different organs into emotions and values, as well as vary in instantiation of common cultural roots. It was shown, for instance, in example (3) that somebody is considered courageous in China if his gallbladder is conceptualised as being visible in size, strength and in (imaginary) number; on the contrary, when you are not brave you are considered to lack this organ. This cultural reference to the gallbladder may seem unusual to a speaker of a different culture, as many internal organs (such as those of the digestive system) may not be naturally referred to and subject to special taboo restrictions. On the other hand, we observe that speakers of occidental cultures in the same context and in their everyday language make reference either to the intestines or to sexual organs, and this strategy may be considered strange or inacceptable by members of other cultures and considered a taboo.

It is interesting to observe that in the case of the same culture broadly referred to as having the same historic roots, as is the case of the Latin culture in Europe, it does not necessarily mean that the conceptualisation is made and the embodiment or cultural grounding are built up in the same way by many different languages of the same culture. For instance, in the case of the courage example (3), we can observe that all the languages studied and illustrating the phenomenon of embodied courage in the same organ, i.e. testicles, relating it with the sexual power of an individual. In an analogous way to what was previously shown in the case of the gallbladder in Chinese, the speakers of these tongues refer to somebody who is not brave as a person with no 
testicles. Although the embodiment of testicles works for the three exemplified languages, each of them instantiates this embodiment in a different euphemistic way used for the taboo reference: balls, in English (and partly in Portuguese), eggs in Polish, and tomatoes in European Portuguese. The same phenomenon is observed in the types of embodiment studied in example (2). Although there may exist the same sort of cultural embodiment in all three of the languages studied here (as observed in the case of an ancient reference to Damocles' sword), the specific linguistic expression differs from language to language, showing some linguistic restriction that have to be mastered if metaphorical competence is expected. In some cases, different languages may use an analogous reference to the same type of activity, but its instantiation again is determined both culturally and linguistically. It can be observed, for instance in example 1, where speakers of both English and Polish refer emotionally to the state of being very hungry as if they wanted to voraciously eat up a large sized animal. Nevertheless, in each case the choice of the animal used in the image is different: the English choose an ox, whereas the Polish choose a horse (with its hooves included) or a wolf.

As the analysis of the examples in our study shows, the figurative language used for the expression of emotions or values in (semi-)fixed linguistic constructions or idioms is neither completely opaque nor arbitrary, but at least partially motivated by their original, literal usage, and can be the object of insightful learning, for example by learning the etymology of figurative expressions and/or history of cultural references in which they are rooted.

In a multilingual context where a (multilingual) speaker learns a new language different from his/her own native tongue, conceptual appropriateness in metaphorical competence and metaphor awareness play a fundamental role in the acquisition of figurative language. While native speakers use metaphorical language quite correctly without any awareness about their origin or grounding, this is not the case in the process of non-native acquisition and learning. In order to be metaphorically competent, a multilingual speaker should understand how new conceptualisations are created and culturally anchored. This means that the Cognition - Language - Culture interaction should be "internalised" by the speaker, leading to both physical and cultural embodiment.

To sum up, if you are a non-native speaker of English coming from a different culture, even if broadly speaking you belong to the same global culture of the same Latin origins, in order to refer in an everyday situation either that you are starving, or you nearly missed a train or even that you admire brave attitudes and heroes, you have to conceptually restructure and learn that your reference has to be made - both culturally and linguistically - for instance to the skin of your teeth, to eating voraciously an ox or to having balls, in a specific English figurative expression. It means that learning a new tongue involves conceptual restructuring - for instance, from the internal clock or a horse with its hooves included to a native English ox - and implies 
transforming into a new cultural system, with courage housed either in the gallbladder or in the testicles, sometimes crossing the boundaries of your native linguistic and cultural taboos. Or, as Yu (2007) puts it metaphorically, you have to switch conceptually from travelling by day to travelling by night:

As language is embedded in culture (Palmer and Sharifian, [2007]), cultural context is the "physical environment" in which language acquisition takes place. However, first language acquisition and second language acquisition are very different. First language acquisition is "traveling by day", whereas second language acquisition is "traveling by night". That is, second language learners have to "feel their way in the dark". Introducing the cultural context to second language learners is to "set up street lights and road signs" for them so that they can "see" where they are going and "go faster". (Yu, 2007: 83).

\section{Acknowledgments}

We would like to thank Margarida Martins for the discussion of the last English version of the paper.

\section{References}

Aleshtar, M. T. and Dowlatabadi, H. (2014). Metaforic competence and language proficiency in the same boat. Procedia - Social and Behavioral Sciences, 98, 1895-1904.

Batoréo, H. (2015). Competência metafórica e linguística cultural: Exemplo de conceptualização de emoções em Chinês e na cultura ocidental (Metaphorical competence and cultural linguistics: Exemples of conceptualizing emotions in Chinese and occidental cultures). Revista Investigações, Universidade Federal de Pernambuco, 28(2), 1-28.

Batoréo, H. (2017a). On ironic puns in Portuguese authentic oral data. In. A. Athanasiadou \& Colston, H. (Eds.), Irony in language use and communication. John Benjamins.

Batoréo, H. (2017b). Metaphorical competence in multilingual context of language acquisition and learning. Ms. Presented at: ICMME 2017 International Conference on Multilingualism and Multilingual Education, University of Minho, Braga, 11-13 May 2017.

Batoréo, H. (2017c). Metaphorical competence and cultural linguistics: Why is it important for a multilingual speaker to be conceptually appropriate while expressing emotions in different languages? Ms. Presented at: Rhetoric Discourse and the Communicative-Dialogical Mind, Lisbon, Faculdade de Letras da Uiniversidade de Lisboa, 7-9 June, 2017.

Boers, F. (2001). Remembering figurative idioms by hypothesising about their origin. Prospect, 16(3), 5-43. 
Boers, F., Demecheleer, M., \& Eyckmans, J. (2004). Etymological elaboration as a strategy for learning idioms. In P. Bogaards \& B. Laufer (Eds.), Vocabulary in a second language (pp. 53-77). Amsterdam: John Benjamins.

Boers, F., Eyckmans, J., \& Stengers, H. (2007). Presenting figurative idioms with a touch of etymology: more than mere mnemonics? Language Teaching Research, 11(1), 43-62.

Clark, J. M. and Paivio, A. 1991: Dual coding theory and education. Educational Psychology Review, 3, 233-62.

Croft, W. \& Cruise, D. A. (2004). Cognitive linguistics. Cambridge: Cambridge University Press.

Dancyngier, B. \& Sweetser, E. (2015). Figurative language. Cambridge: Cambridge University Press.

Danesi, M. (1992). Metaphorical competence in second language acquisition and second language teaching: The neglected dimension. In J. E. Alatis (Ed.), Georgetown University round table on languages and linguistics (pp. 125136). Washington, DC: Georgetown University Press.

Danesi, M. (1993). Metaphorical competence in second language acquisition and second language teaching: The neglected dimension. In J. E. Alatis (Ed.), Language, communication and social meaning (pp. 489-500). Washington, DC: Georgetown University Press.

Danesi, M. (1995). Learning and teaching languages: the role of conceptual fluency. Applied Linguistics, 5(1), 3-20.

Doiz, A., \& Elizari, C. (2013). Metaphoric competence and the acquisition of figurative vocabular in foreign language. ELIA - Estudios de Linguística Inglesa Aplicada, 13, 47-82.

Gibbs, R. W. (1994). The poetics of mind: Figurative language, thought and understanding. New York, NY: Cambridge University Press.

Gibbs, R. W. (Ed.). (2008). The Cambridge handbook of metaphor and thought. Cambridge: Cambridge University Press.

Gibbs, R. W., \& Colston, H. (2012). Interpreting figurative meaning. Cambridge: Cambridge University Press.

Kövecses, Z. (1990). Emotion concepts. Springer-Verlag.

Kövecses, Z. (2005). Metaphor in culture: Universality and variation. Cambridge: CUP.

Lakoff, G. (1987). Women, fire and dangerous things: What categories reveal about the mind. Chicago, IL: Chicago University Press.

Lakoff, G. \& Johnson, M. (1980). Metaphors we live by. Chicago, IL: University of Chicago Press.

Ots, T. (1990). The angry liver, the anxious heart and the melancholy spleen. Culture, Medicine and Psychiatry, 14(1). 21-58. 
Palmer, G. \& Sharifian, F. (2007). Applied cultural linguistics: An emerging paradigm". In: F. Sharifian \& G. Palmer (Eds.). (2007). Applied cultural lingusitics: Implications for second language learning and intercultural communication (pp. 1-14), Amsterdam/Philadelphia : John Benjamins.

Sharifian, F. (2011). Cultural linguistics. Inaugural Professoral Lecture, Professor Farzad Sharafian, School of Language, Cultures, and Linguistics, Language and Society Centre, Monash University. http://monash.academia. edu/ProfessorFarzadSharifian/Papers/611702/Cultural_Linguistics_Farzad_ Sharifians_Inaugural_Professorial_Lecture

Sharifian, F. (2015). Cultural Linguistics. In F. Sharifan (Ed.), The Routledge handbook of language and culture (pp. 473-493). Oxford: Routledge.

Sharifian, F. \& Palmer, G. B. (Eds.). (2007). Applied cultural linguistics: Implications for second language learning and intercultural communication. Amsterdam/Philadelphia: John Benjamins.

Sharifian, F., Dirven, R., Yu, N., \& Neiemier, S. (Eds.). (2008). Culture, body, and language: Conceptualizations of internal body organs across cultures and languages. Berlin/New York: Mouton de Gruyter.

Shirazi, M. G. \& M. R. Talebinezhad (2013). Developing intermediate EFL learners metaphorical competence through exposure. Theory and Practice in Language Studies, 3(1), 135-141.

Sinha, Ch. \& Jensen de López, K. (2004). Language, culture and the embodiment of spatial cognition. Cognitive Linguistics, 11, 17-41.

Yu, N. (1995). Metaphorical expressions of anger and happiness in English and Chinese. Metaphor and Symbolic Activity, 10(2), 59-92.

$\mathrm{Yu}, \mathrm{N}$. (1998). The contemporary theory of metaphor: a perspective from Chinese. Amsterdam: John Benjamins Publishing Company.

Yu, N. (2003). Metaphor, body, and culture: The Chinese understanding of gallbladder and courage. Metaphor and Symbol, 18(1), 13-31.

$\mathrm{Yu}, \mathrm{N}$. (2007). The Chinese conceptualization of the heart and its cultural contexto. Implications for second language learning. In F. Sharifian \& G. B. Palmer (Eds.), Applied cultural linguistics: Implications for second language learning and intercultural communication (pp. 65-86). Amsterdam: John Benjamins.

Yu, N. (2008a) Metaphor from body and culture. In R. W. Gibbs, Jr. (Ed.), The Cambridge handbook of metaphor and thought (pp. 247-261). Cambridge: Cambridge University Press.

Yu, N. (2008b). The Chinese heart as the central faculty of cognition. In F. Sharifian, R. Dirven, N. Yu, \& S. Niemeier (Eds.), Culture, body, and language: Conceptualizations of internal body organs across cultures and languages (pp. 131-168). Berlin: Mouton de Gruyter

Yu, N. (2009). From body to meaning in culture. Amsterdam/Philadelphia: John Benjamins Publishing Company. 


\section{Extra references: Websites with linguistic expressions:}

\section{English}

https://www.merriam-webster.com/dictionary/courage

https://www.englishexperts.com.br/forum/como-dizer-estar-por-um-fio-emingles-t7340.html

http://www.dictionary.com/browse/have-the-guts

http://www.phrases.org.uk/meanings/83000.html

https://idioms.thefreedictionary.com/by+the+skin+of +teeth

\section{European Portuguese}

http://www.urbandictionary.com/define.php?term=have $\% 20$ the $\% 20$ ball, https://pt.wiktionary.org/wiki/triz.

http://www.dicionarioinformal.com.br/ter\%20est $\% \mathrm{C} 3 \% \mathrm{~B} 4 \mathrm{mago} /$

$\mathrm{http}: / / \mathrm{www}$.dicionarioinformal.com.br/por+um+fio/

https://www.significados.com.br/por-um-triz/

\section{Polish}

http://www.szkolaojcostwa.pl/artykuly/meska-odwaga/

http://sjp.pwn.pl/slowniki/o\%20w\%C5\%82os.html;

https://sjp.pwn.pl/poradnia/haslo/Smierc-jest-o-wlos;16627.html

http://www.edupedia.pl/words/index/show/475215_slownik frazeologiczny-miec_cos_na_watrobie. http://www.edupedia.pl/words/ index/show/476012_slownik_frazeologiczny-przewracaja_sie__ komus kiszki_flaki_i_in_pot.html 